Article

\title{
Exploring the Prevalence of Protective Measure Adoption in Mosques during the COVID-19 Pandemic in Indonesia
}

\author{
Choirul Amin ${ }^{1, *(D)}$, Priyono Priyono ${ }^{1}$, Umrotun Umrotun ${ }^{1}$, Maulida Fatkhiyah ${ }^{1}$ and Suliadi Firdaus Sufahani ${ }^{2}$ \\ 1 Faculty of Geography, Universitas Muhammadiyah Surakarta, Surakarta 57162, Indonesia; \\ pri222@ums.ac.id (P.P.); umr166@ums.ac.id (U.U.); maulida.ftkyh@gmail.com (M.F.) \\ 2 Faculty of Sciences Technology and Human Development, University Tun Hussein Onn Malaysia, \\ Batu Pahat 86400, Johor, Malaysia; suliadi@uthm.edu.my \\ * Correspondence: ca122@ums.ac.id
}

Citation: Amin, C.; Priyono, P.; Umrotun, U.; Fatkhiyah, M.; Sufahani, S.F. Exploring the Prevalence of Protective Measure Adoption in Mosques during the COVID-19 Pandemic in Indonesia. Sustainability 2021, 13, 13927. https://doi.org/ $10.3390 /$ su132413927

Academic Editor: Lionel Obadia

Received: 18 October 2021

Accepted: 13 December 2021

Published: 16 December 2021

Publisher's Note: MDPI stays neutral with regard to jurisdictional claims in published maps and institutional affiliations.

Copyright: (c) 2021 by the authors. Licensee MDPI, Basel, Switzerland. This article is an open access article distributed under the terms and conditions of the Creative Commons Attribution (CC BY) license (https:/ / creativecommons.org/licenses/by/ $4.0 /)$.

\begin{abstract}
Muslims worship together more frequently than members of other religions. They pray in congregation at the mosque five times a day, causing the mosque to become a central hub for COVID-19 transmission. Therefore, the adoption of protective measures as a method of mitigating the COVID-19 pandemic in mosques is vital. This study aims to account for the implementation status of protective measures in mosques in Surakarta City, Indonesia, during the COVID-19 pandemic. A cross-sectional survey was conducted using a structured questionnaire sent to mosque caretakers as research participants. The mosques were chosen using a simple random sampling technique for a total sample of 247 mosques in Surakarta City. Participants were asked how often they implement the following protective measures in mosques, as recommended by the Majelis Ulama Indonesia: checking body temperature before entering the mosque, prayer distancing, carrying own prayer mat, wearing a mask when praying and no handshaking after prayer. The prevalence of the adoption of protective measures was revealed to be amongst $44.6 \%$ to $92.6 \%$, with the lowest prevalence in checking body temperature before entering the mosque. Overall, only $33.7 \%$ of mosques implemented all protective measures. In mosques affiliated with Nahdlatul Ulama and the small mosques, the prevalence of protective measures was lower than in mosques affiliated with Muhammadiyah and the large mosques, respectively, suggesting that it is crucial to develop targeted health messages for these groups. Finally, as religious communities remain active in congregational worship during the outbreak, the contradictions between medical and religious practices must be addressed in society for believers to adopt public health policies and for policymakers to comprehend the importance of religious observances.
\end{abstract}

Keywords: COVID-19; congregational prayer; mosque; protective measure; Muslim; Indonesia

\section{Introduction}

Religious activities have suffered a significant setback due to the COVID-19 pandemic, which has no precedent in history. In March 2020, numerous religious institutions, including mosques, were closed to contain the virus's spread [1]. Many incidences of COVID-19 transmission have occurred in various countries due to religious and worship events. In Germany, for example, more than 100 people were infected with COVID-19 after church services [2]. In the U.S., the epicenter of the state's massive coronavirus outbreak was a church in the countryside of northeastern Oregon, where 236 people tested positive for the infection [3]. In South Korea, 5209 Christian congregations tested positive for COVID-19 on 9 February 2020, at the Shincheonji Church of Jesus [4,5]. A drastic increase in COVID19 incidents also occurred in Malaysia-as many as 1545 from 27 February to 3 March 2020 - allegedly due to a meeting of the Tablighi Jamaat, the attendants of which came from several countries, including Indonesia [6-8].

One of the critical ways in which this global pandemic altered the religious landscape is the effect of societal changes brought about by COVID-19 on religious institutions, 
congregations and individuals [9]. In many countries, actions to minimize personal contact and gatherings, such as the closing of places of worship, schools, malls and offices, have been undertaken to avert the rapid transmission of COVID-19 [10,11]. While several examples have documented religious gatherings operating as COVID-19 spread events, most congregations have complied with government instructions to close. However, some resisted those orders, remaining open and posing the risk of COVID-19 transmission. Authorities' cautions that meetings should be kept to a minimum to prevent the virus from spreading are at odds with believers [12].

Muslims worship together more frequently than people of other religions. At least five times a day, Muslims perform obligatory prayers in the congregation at the mosque, namely prayer Isha, Fajr, Dhuhur, Asr and Maghrib [13]. An adult Muslim male who has no excuses for not praying in the congregation is obligated to do so. Nevertheless, doing so during a pandemic can bolster the spread of COVID-19. Therefore, the mosque as a place where congregational prayers are performed is one of the places most prone to spreading COVID-19.

Indonesia is a country with one of the most prominent Islamic communities in the world. More than 207 million Muslims make up 87.2\% of the entire population [14]. In addition, Indonesia is the country with the greatest number of mosques in the world. In 2021, The Religious Affairs Ministry to make a comprehensive count of the number of mosques in Indonesia is 741,991.

When an area is declared a red zone, strict health regulations are implemented. The government announced a policy of suspending prayer and enforcing stringent regulations to limit the number of worshipers in mosques and other places of worship to forestall the contagion of COVID-19 [6]. Almost all religious communities are ready to modify their worship practices, while others suspend or drastically reduce their spiritual practices [15].

In many countries that have imposed a lockdown to contain COVID-19, congregational prayer in mosques has been suspended due to public health concerns. Nonetheless, Indonesia has permitted mosques to open for congregational prayers while still adhering to protective measures. The World Health Organization (WHO) suggests the following five primary COVID-19 protective measures: hand hygiene; avoiding touching the eyes, nose, and mouth; respiratory etiquette; social distancing and self-isolation [16]. Moreover, the Majelis Ulama Indonesia (MUI) issued Fatwa No. 14 of 2020 regarding religious conduct in COVID-19 pandemic situations. This fatwa, according to the MUI, is a religious guide for the community, particularly Muslims, to continue performing religious activities in accordance with Shariah principles and pay careful attention to protective measures for the prevention of COVID-19 [17]. The main points of this fatwa include prohibiting sick people from praying in mosques (by checking body temperature before entering the mosque), prayer distancing, carrying own prayer mat, wearing a mask when praying and no handshaking after prayer. These preventive measures might be helpful, but there is still a possible risk of COVID-19 spreading [1].

Therefore, how well the community adopts these protective measures during the pandemic is a crucial issue. As a consequence, protective measures must be established as a method of mitigating the pandemic. Protective measures can help a pandemic spread more slowly and have a lesser impact. The use of protective measures is justified as part of a broader pandemic response strategy [18]. COVID-19 is a highly contagious virus that can be prevented by increasing the frequency and type of preventive measures, as well as the number of activities performed [19]. Therefore, failure to maintain an appropriate protective measure in congregational prayer contributes to the uncontrolled transmission of the virus [20].

In light of the previous study, this study looks into the implementation status of protective measures in mosques in Surakarta City during the COVID-19 outbreak. 


\section{Materials and Methods}

\subsection{Study Area}

A cross-sectional study of protective measures adopted in mosques in Surakarta City was conducted. The survey was organized between 10 May and 15 May 2021. At the time of the survey, there were 3482 confirmed cases of COVID-19 in Indonesia [21]. In May 2021, Indonesia experienced a 15.1\% increase in COVID-19 cases compared to the previous month. Meanwhile, Surakarta City in May 2021 is included as one of the five cities with the highest death rates in Indonesia, which is 105.18 per 100,000 population [22] (Figure 1). Regarding the COVID-19 outbreak, Surakarta City is of particular importance because it is where the first COVID-19 patient died in Central Java on 11 March 2020. Surakarta was also the first to declare the COVID-19 Extraordinary Occurrence Status in Indonesia [23].

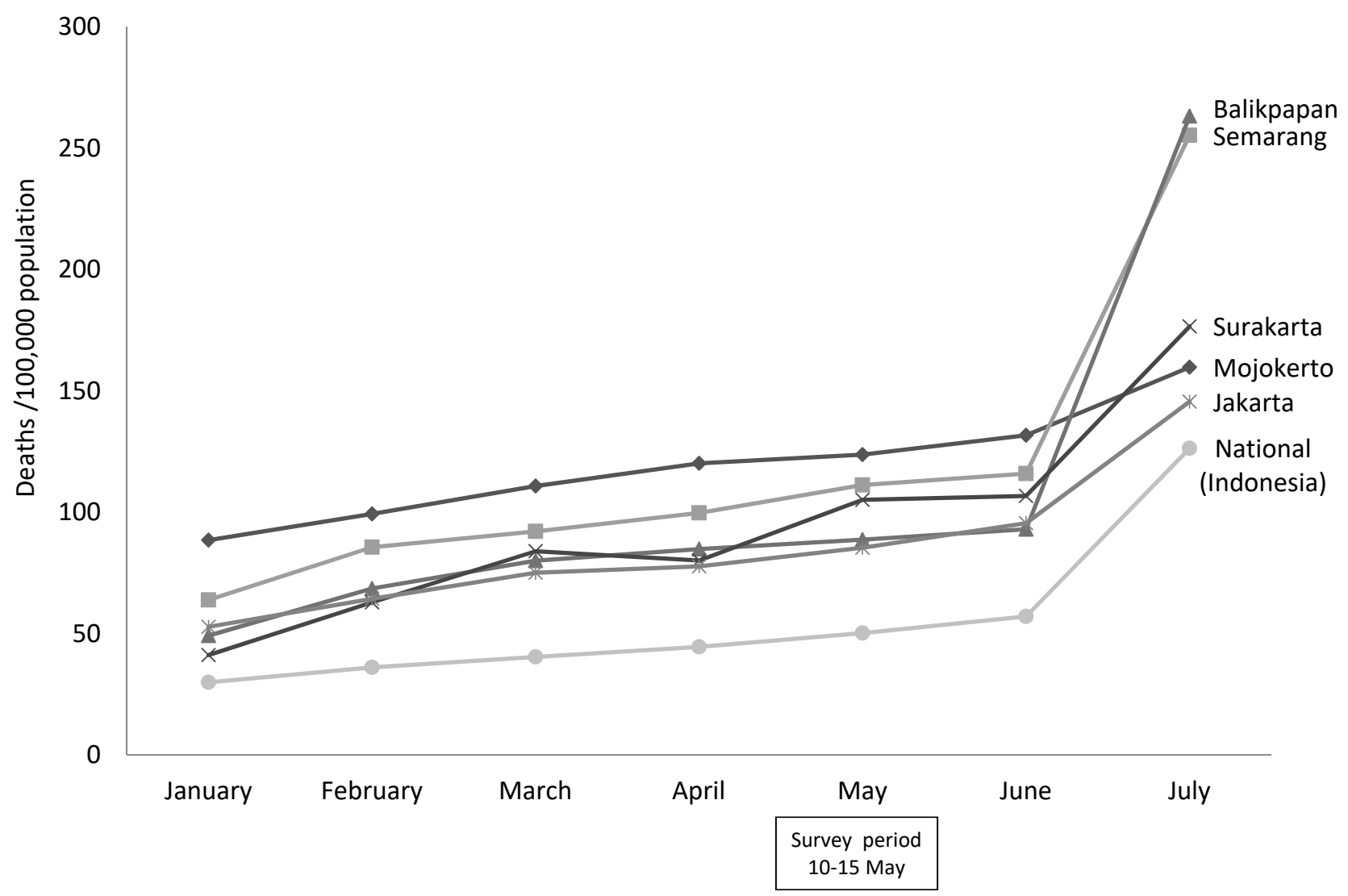

Figure 1. The five cities with the highest death rates in Indonesia during this survey period. Generated according to the National COVID-19 Task Force situation report (National COVID-19 Task Force, 2021).

Surakarta City is located $536 \mathrm{~km}$ east of Indonesia's capital city (Jakarta) (Figure 2). The city has an administrative area of approximately 44 square $\mathrm{km}$ and a total population of 522,264 (2020). Muslims make up the majority of the population in this city. Surakarta City has 456,107 Muslim residents (87.3 percent of the population) [24]. Surakarta has played a critical role in the spread of Islam in Java. The existence of the Mataram Islam dynasty's palace in Surakarta is inextricably linked to the spread of Islam. The mosque was built by the kingdom as a means of spreading Islam at the time. The Laweyan Mosque, built in 1546 and one of Java's oldest mosques, is located in Surakarta. There are currently 684 mosques in Surakarta City. 


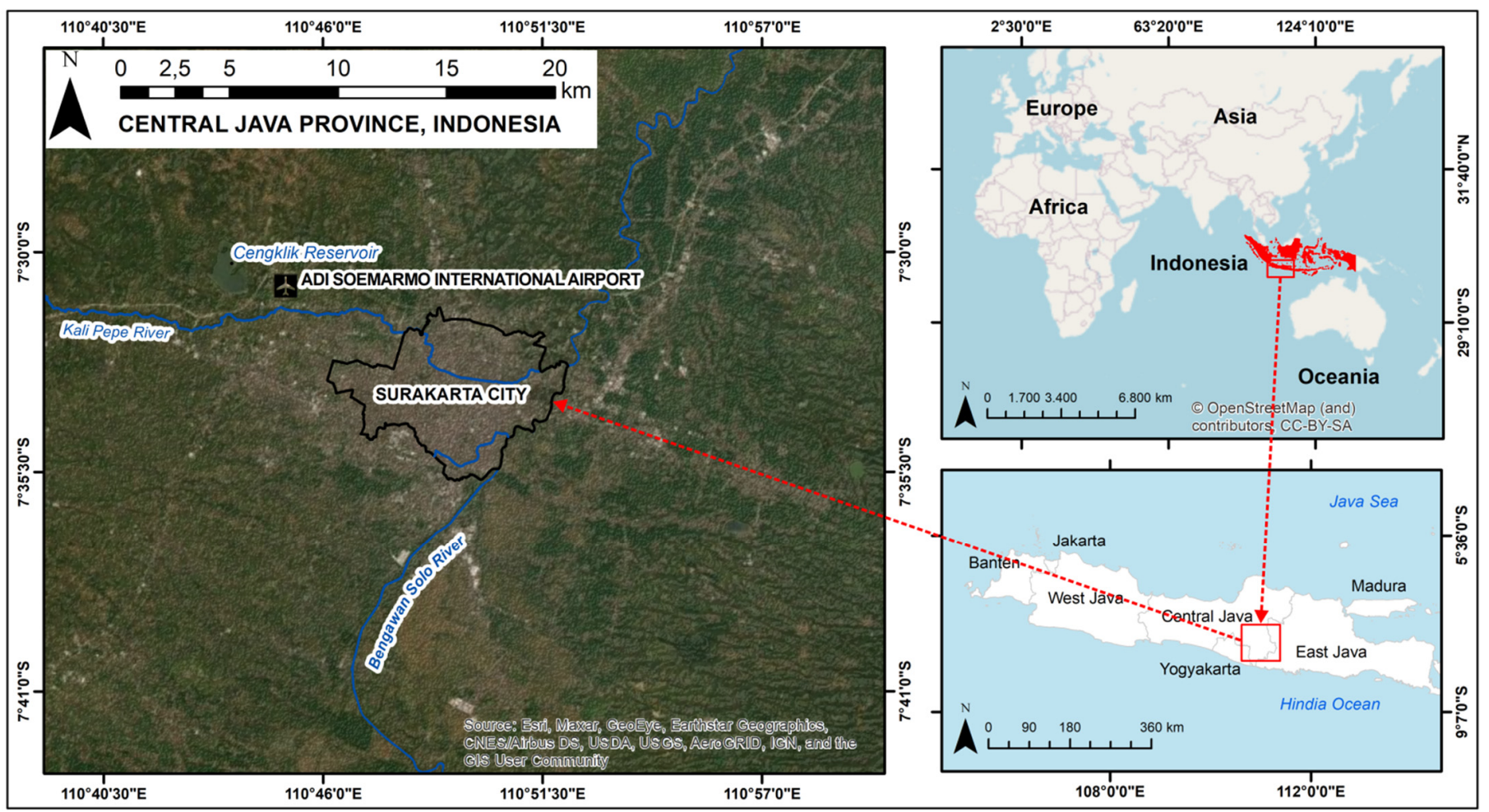

Figure 2. The study area of the cross-sectional survey. Surakarta City, Central Java, Indonesia.

\subsection{Sample Calculation and Sample Selection}

In order to determine the number of samples, the Raosoft Sample Size Calculator was utilized [25]. For a population of 684 mosques in Surakarta City with a 95\% confidence interval and 5\% margin of error, the estimated samples were 247 . The $\mathrm{r} 2$ was used to evaluate the sample size effect [26].

The participants in this study were the mosque caretakers. Congregations appoint mosque caretakers to manage mosques and maintain them. Caretakers are in charge of arranging religious services in the mosque. They are responsible for the upkeep of mosque buildings and facilities of worship, as well as the selection of imams to lead five prayer times, deliver sermons, perform the call to prayers and commemorate religious holidays and other social events.

Participants were recruited using a simple random sampling method. A list of mosques in Surakarta city was obtained from the Mosque Information System, Ministry of Religion. We numbered and selected mosques by a simple randomization method using a computer-generated random sequence. All mosque caretakers in the selected mosque were surveyed until the required sample sizes were fulfilled.

\subsection{Data Collection and Measurement}

A team of researchers, assisted by two assistants, collected the data. The surveyors had been adequately briefed and trained before they began collecting data. A set of structured questionnaires was administered by means of surveying a sample of 247 mosque caretaker respondents. The questionnaires covered three domains: (1) the mosque caretaker's attributes (sex, age, education attainment and years being mosque caretakers); (2) the mosque characteristics (the affiliation of the mosque to an Islamic organization, the mosque's age, the mosque's size and the number of worshippers in each congregational prayer) and (3) the protective measures implemented in the mosque (checking body temperature before entering the mosque, prayer distancing, carrying own prayer mat, wearing a mask when praying and no handshaking after prayer) [17]. 
Participants described the adoption of protective measures recommended by the Fatwa of the Indonesian Ulema Council [17]. Regarding the performance of checking body temperature before entering the mosque (prohibiting sick people from praying in mosques) and the implementation of prayer distancing, participants were questioned about the frequency with which these were implemented at their mosque throughout the previous week, responding using a four-point Likert scale (1. "Always," 2. "Sometimes," 3. "Rarely" or 4. "Never"). As for the performance of the measures of carrying their own prayer mat, wearing a mask when praying and not handshaking after prayer, participants were asked the percentage of worshippers performing these measures. Participants replied using a four-point Likert scale (1. "100\% (all of the pray-ers)," 2. ">75\% (most of the pray-ers)," 3. " $<25 \%$ (a few of the pray-ers)" or 4 . "0\% (none of the pray-ers)."

\subsection{Statistical Analysis}

Regarding protective measures in the mosque, it was determined that they were applied when a participant answered 1 ("Always" / "All of them") or 2 ("Frequently" / Most of them") on the 4-point-Likert scale, referred to as "loose criteria" in this study. We illustrate the predominance of every protective measure while adopting all of them. The proportion of mosques for each overall number of protective measures implemented was likewise refined. The prevalence of protective measures was counted up through the selection of 1 ("Always" / All of them") on the four-point Likert scale; this was considered as adopting protective measures and referred to as "strict criteria" in this study. A multivariate logistic regression analysis was performed to understand the relationship between each mosque's characteristics and adopt all protective measures recommended by the MUI. The dependent variable was the adoption of all protective measures in accordance with the loose criteria. The independent variables were the age of the mosque, the floor area of the mosque and the number of worshipers in each congregational prayer. IBM SPSS Statistics for Windows, version 23, was used to perform the statistical analysis.

\section{Results}

\section{Characteristics of Mosque and Mosque Caretaker}

A total of 247 mosques were observed in the study area, of which 247 mosque caretaker participants completed surveys. Table 1 shows the characteristics of the study sample. Most of the mosques (51.1\%) had no affiliation to any Islamic organization. The mean mosque age was $28.6( \pm 23.2)$ years. The mosques have an average floor area of 330.7 $( \pm 223.8)$ square meters, with an average attendance of $36( \pm 20.6)$ worshippers at each congregational prayer. As a result, in each congregational prayer, one worshipper occupies about 9.3 square meters on average. This shows that during the COVID-19 pandemic in the study area, the density of worshipers inside the mosque is very low.

Among the survey participants, as shown in Table 1, the percentage of men and women was $100 \%$ and $0 \%$, respectively, suggesting that all of the mosque caretakers are male. Most of the participants were married (97.2\%), and only a small proportion were widowers $(2.8 \%)$. The average age of the study participants is $44.4( \pm 11.6)$ years, indicating that the middle-aged are the main participants. The distribution of senior high school degrees was the highest in the study participants (59.1\%), followed by junior high school degrees (20.4\%), primary school degrees (10.8\%) and bachelor's degrees $(9.7 \%)$, indicating that most of the mosque caretakers have a senior high school education. The average length of time as a mosque caretaker is $8.1( \pm 5.4)$ years, indicating that the study participants have been mosque caretakers for a long time.

Table 2 represents the proportion of participants for each frequency of COVID-19 protective measures in the mosque recommended by the MUI. Almost half of the participants (42.2\%) admitted never checking the worshipper's body temperature before entering the mosque. In congregational prayer, most of the participants (62\%) applied prayer distancing. Most of the pray-ers frequently $(41.3 \%)$ brought their own prayer mat when praying at 
the mosque. More than one third of worshippers (35.9\%) wore a mask when praying. Avoidance of handshaking after prayer was relatively frequent $(60.9 \%)$.

Table 1. Characteristics of Mosque and Mosque Caretakers.

\begin{tabular}{|c|c|c|}
\hline & \multicolumn{2}{|c|}{$N=247$} \\
\hline & $n$ & $\%$ \\
\hline \multirow{2}{*}{\multicolumn{3}{|c|}{$\begin{array}{l}\text { Mosque characteristics } \\
\text { The mosque's affiliation to an Islamic organization }\end{array}$}} \\
\hline & & \\
\hline No affiliation & 126 & 51.1 \\
\hline Majelis Tafsir Alquran & 16 & 6.5 \\
\hline Nahdlatul Ulama & 40 & 16.3 \\
\hline Muhammadiyah & 64 & 26.1 \\
\hline \multicolumn{3}{|l|}{ The mosque's age (years) } \\
\hline$<10$ & 38 & 15.2 \\
\hline $10-50$ & 175 & 70.7 \\
\hline$>50$ & 35 & 14.1 \\
\hline \multicolumn{3}{|c|}{ The mosque's floor area (square meters) * } \\
\hline$<250$ & 142 & 57.6 \\
\hline $250-500$ & 54 & 21.7 \\
\hline$>500$ & 51 & 20.7 \\
\hline \multicolumn{3}{|c|}{ The number of worshippers in each congregational prayer } \\
\hline$<20$ & 83 & 33.7 \\
\hline $20-50$ & 110 & 44.6 \\
\hline$>50$ & 54 & 21.7 \\
\hline \multicolumn{3}{|l|}{ Mosque caretaker's characteristics } \\
\hline \multicolumn{3}{|l|}{ Gender } \\
\hline Male & 247 & 100.0 \\
\hline Female & 0 & 0.0 \\
\hline \multicolumn{3}{|l|}{ Marital status } \\
\hline Married & 240 & 97.2 \\
\hline Widowed & 7 & 2.8 \\
\hline \multicolumn{3}{|l|}{ Age (Years) } \\
\hline$<30$ & 46 & 18.5 \\
\hline $30-39$ & 64 & 26.1 \\
\hline $40-49$ & 107 & 43.5 \\
\hline $50-59$ & 21 & 8.7 \\
\hline$>60$ & 8 & 3.3 \\
\hline \multicolumn{3}{|l|}{ Education attainment } \\
\hline Primary & 27 & 10.8 \\
\hline Junior high school & 50 & 20.4 \\
\hline Senior high school & 146 & 59.1 \\
\hline University graduate or above & 24 & 9.7 \\
\hline \multicolumn{3}{|c|}{ Length of time as mosque caretaker (years) } \\
\hline$<5$ & 13 & 5.3 \\
\hline $5-10$ & 153 & 61.8 \\
\hline$>10$ & 81 & 32.9 \\
\hline
\end{tabular}

* Larger mosques tend to be located in suburban areas, and some are close to the Surakarta palace, while smaller mosques are mainly located in densely populated settlements.

Figure 3 illustrates the prevalence of COVID-19 protective measures recommended by the MUI, whereas Figure 4 shows the proportion of mosques for each total number of protective measures implemented. Using the loose criteria as a standard, approximately $80 \%$ of mosques implemented prayer distancing, wearing a mask when praying and no handshaking after prayer. However, $53.3 \%$ and $44.6 \%$ implemented carrying their own prayer mat and checking body temperature before entering the mosque. The prevalence of the loose and strict criteria of adoption of all protective measures was $33.7 \%$ and $7.6 \%$, respectively. 
Table 2. The proportion of participants for each frequency of MUI-recommended COVID-19 protective measures in the mosque.

\begin{tabular}{|c|c|c|c|c|c|}
\hline & $N$ & 1. Always & 2. Sometimes & 3. Rarely & 4. Never \\
\hline & & $n(\%)$ & $n(\%)$ & $n(\%)$ & $n(\%)$ \\
\hline $\begin{array}{l}\text { Checking body temperature } \\
\text { before entering the mosque }\end{array}$ & 247 & $48(19.6)$ & $62(25.0)$ & $32(13.0)$ & $105(42.4)$ \\
\hline \multirow[t]{3}{*}{ Prayer distancing } & 247 & $153(62.0)$ & $46(18.5)$ & $27(10.8)$ & $21(8.7)$ \\
\hline & & $\begin{array}{l}\text { 1. All of the } \\
\text { pray-ers }\end{array}$ & $\begin{array}{l}\text { 2. Most of the } \\
\text { pray-ers }\end{array}$ & $\begin{array}{l}\text { 3. A few } \\
\text { pray-ers }\end{array}$ & $\begin{array}{l}\text { 4. None of the } \\
\text { pray-ers }\end{array}$ \\
\hline & & $n(\%)$ & $n(\%)$ & $n(\%)$ & $n(\%)$ \\
\hline Carrying own prayer mat & 247 & $30(12.0)$ & $102(41.3)$ & $73(29.3)$ & $43(17.4)$ \\
\hline Wearing a mask when praying & 247 & $89(35.9)$ & $86(34.8)$ & $51(20.7)$ & $21(8.7)$ \\
\hline No handshaking after pray & 247 & $78(31.5)$ & $150(60.9)$ & $13(5.4)$ & $5(2.2)$ \\
\hline
\end{tabular}

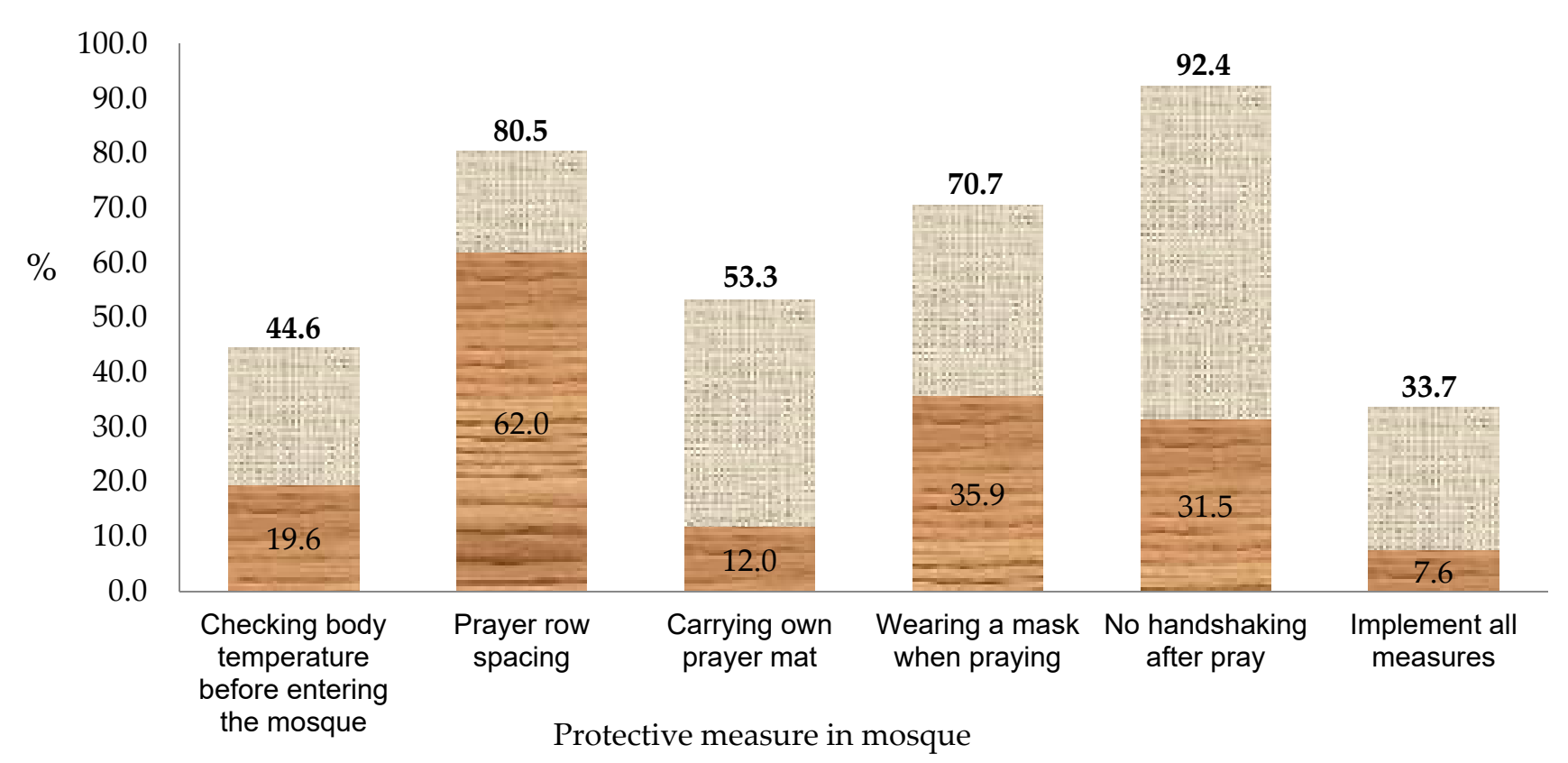

Always/All of prayers $\quad$ Sometimes/Most of prayers

Figure 3. The prevalence of protective measures in mosques recommends by the MUI.

The multivariate logistic regression that explained the implementation of all protective measures in the mosque obtained a Cox and Snell R-squared of 0.306 and a Nagelkerke R-squared of 0.385 . Mosques affiliated with Nahdlatul Ulama had two times lower odds $(\mathrm{OR}=0.510 ; 95 \% \mathrm{CI}: 0.073-1.240)$ of implementing all protective measures than mosques affiliated with Muhammadiyah. Mosques aged $<10$ years had nine times higher odds of implementing all protective measures (OR = 9.304; 95\% CI: 2.826-30.633) compared with the older mosques (mosque aged $>50$ years). When compared with the large mosques ( $>500$ square meters floor area), small mosques ( $<250$ square meters floor area) had almost two times lower odds of implementing all protective measures $(\mathrm{OR}=0.470 ; 95 \% \mathrm{CI}$ : $0.084-1.573)$. The number of worshipers was significantly $(p<0.001)$ associated with higher odds of implementing all protective measures. Mosques with small congregations ( $<20$ worshipers) had one and a half times higher odds of implementing all protective measures $(\mathrm{OR}=1.590$; 95\% CI: 0.702-3.615) compared with those mosques with large congregations ( $>50$ worshipers). Details are presented in Table 3 . 


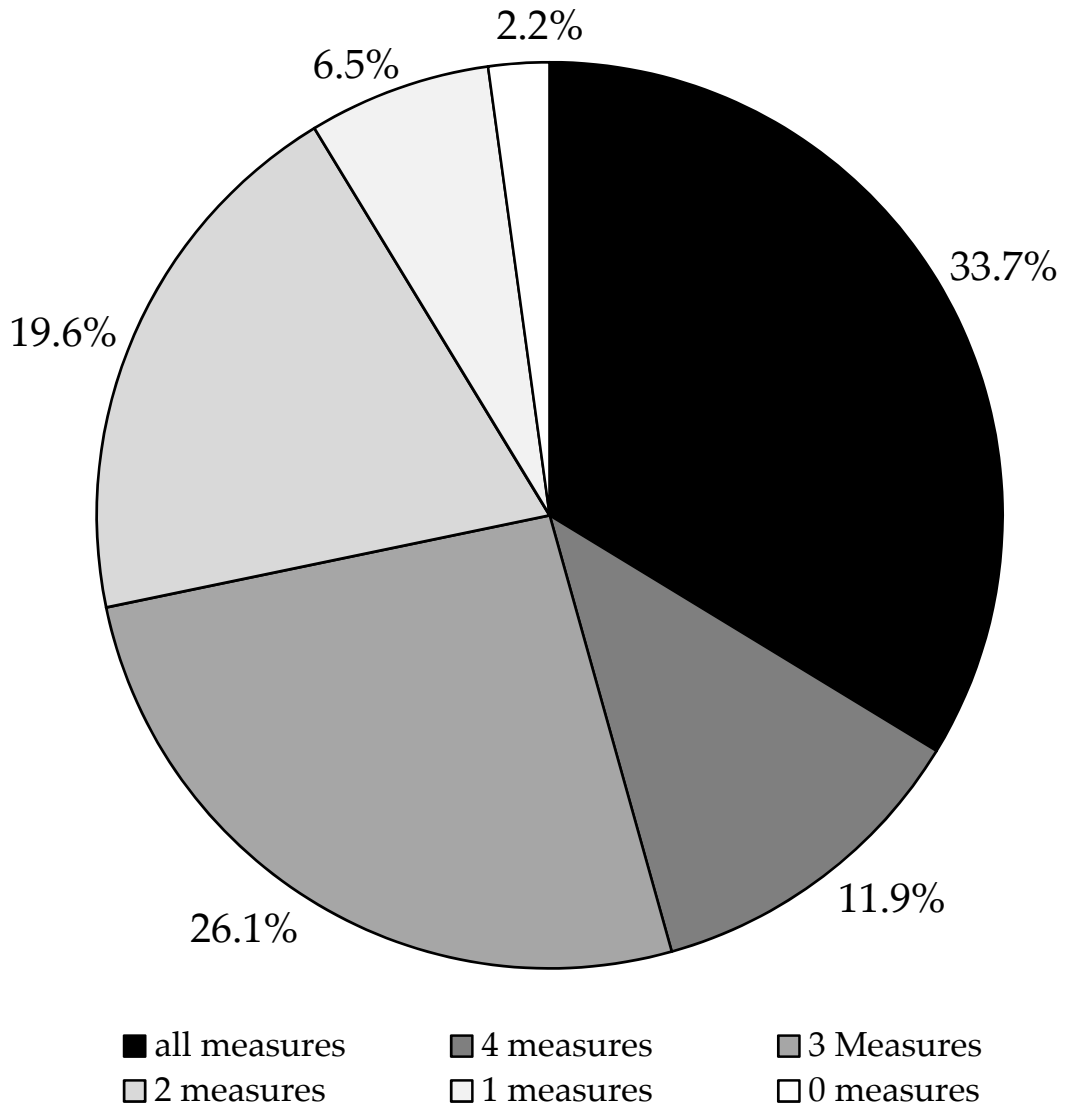

Figure 4. The proportion of mosques for each total number of implementing protective measures. When a participant responded "Always," "Sometimes," "All of the pray-ers," or "Most of the prayers" for each protective measure, it was treated that the protective measure had been adopted.

Table 3. The association between each mosque characteristic and the implementation of all MUI-recommended protective measures in mosques.

\begin{tabular}{|c|c|c|c|c|c|}
\hline \multirow[t]{2}{*}{ Variable } & \multirow[t]{2}{*}{$n$} & \multirow[t]{2}{*}{$p$-Value } & \multirow[t]{2}{*}{ Odds Ratio } & \multicolumn{2}{|c|}{ 95\% Confidence Interval } \\
\hline & & & & Lower & Upper \\
\hline \multicolumn{6}{|c|}{ The mosque's affiliation to an Islamic organization } \\
\hline No affiliation & 126 & 0.778 & 0.897 & 0.420 & 1.913 \\
\hline Majelis Tafsir Alquran & 16 & 0.102 & 0.302 & 0.072 & 1.268 \\
\hline Nahdlatul Ulama & 40 & 0.016 & 0.510 & 0.073 & 1.240 \\
\hline Muhammadiyah & 64 & Ref. & Ref. & Ref. & Ref. \\
\hline \multicolumn{6}{|l|}{ The mosque's age (years) } \\
\hline$<10$ & 38 & $<0.001$ & 9.304 & 2.826 & 30.633 \\
\hline $10-50$ & 175 & 0.263 & 1.775 & 0.650 & 4.844 \\
\hline$>50$ & 35 & Ref. & Ref. & Ref. & Ref. \\
\hline \multicolumn{6}{|c|}{ The mosque's floor area (square meters) } \\
\hline$<250$ & 142 & 0.039 & 0.470 & 0.084 & 1.573 \\
\hline $250-500$ & 54 & 0.194 & 0.485 & 0.162 & 1.447 \\
\hline$>500$ & 51 & Ref. & Ref. & Ref. & Ref. \\
\hline \multicolumn{6}{|c|}{$\begin{array}{c}\text { The number of worshipers in each congregational } \\
\text { prayer (person) }\end{array}$} \\
\hline$<20$ & 83 & $<0.001$ & 1.590 & 0.702 & 3.615 \\
\hline $20-50$ & 110 & $<0.001$ & 1.271 & 0.576 & 2.841 \\
\hline$>50$ & 54 & Ref. & Ref. & Ref. & Ref. \\
\hline
\end{tabular}




\section{Discussion}

We aimed to investigate the prevalence of protective measures in mosques in Surakarta city during the COVID-19 pandemic. The prevalence of each protective measure in mosques recommended by the MUI ranged from $44.6 \%$ to $92.6 \%$. Under the loose criteria, only $33.7 \%$ of participants adopted all measures, and the prevalence was further reduced to only $7.6 \%$ when strict criteria were employed. The finding implies that the protective measures adopted by the mosques are insufficient. While mosques remain open in times of pandemic and do not adhere to protective measures properly, this can give the impression that worshippers are not complying with authorities' cautions, as indicated by [12]. On the other hand, it may imply that religious believers in Indonesia cannot simply adapt their religious rituals in reaction to the COVID-19 pandemic. It is not easy for worshippers to balance practicing congregational prayer and maintaining protective measures in a pandemic situation. This, however, may be explained by the premise that most nonWestern communities do not agree with the notion that religious practices can simply be modified under exceptional conditions, such as the present pandemic [27].

The prevalence of the adoption of protective measures among those in mosques affiliated with Nahdlatul Ulama and the small mosques was lower in mosques affiliated with Muhammadiyah and the larger mosques, respectively. This disparity in the prevalence of the adoption of protective measures among mosques cannot be separated from the characteristics of the religious organizations to which they are affiliated. In response to the government's appeal for mosques not to hold congregational prayers to contain the transmission of COVID-19, Muhammadiyah mosques made persuasive, cautious and rational approaches to convey the content of the government's call to their congregations. In contrast, the content of the calls transmitted to the congregation by the Nahdlatul Ulama mosques promoted disregard for the government's appeal [28]. It is arduous to assess if the prevalence described in this study is high or low by global standards. However, it showed that there is potential for enhancement in adopting protective measures among mosques in Surakarta City, particularly those affiliated with Nahdlatul Ulama and the small mosques.

Even though the prevalence of all protective measures was generally higher in this study than in the United Kingdom on 17-18 March 2020 [29], the prevalence of checking body temperature before entering the mosque was particularly low. In mosques, these protective measures may still leave a lot to be desired. To take the temperature of any person before they enter a public place is one of the measures to limit the risk of a person introducing COVID-19 into a public place. As governments and localities undertake to reopen plans during the COVID-19 pandemic, a non-contact temperature-assessment appliance could be utilized as a part of a preliminary check at entrance points to detect and triage persons with elevated temperatures and COVID-19 symptoms. Nevertheless, temperature testing should not be a substitute for the most effective control measures, because thermal scanners only pick up body surface temperature, not true fever [30]. However, thermal scanners efficiently detect people with a fever (i.e., people who have a higher-than-normal body temperature) because of infection. Therefore, to decrease the chance of COVID-19 spreading, sick people are not allowed to pray in mosques and are subjected to temperature checking before entering. This temperature check also serves to emphasize the importance of not going to the mosque if unwell.

The prevalence of wearing a mask when praying was exceptionally high in this study. Throughout the beginning phases of the COVID-19 outbreak, worshippers' interest in precautionary measures was focused on wearing face masks. Particular protective measures may not be as successful when employed alone. Therefore, they should be used in combination with other treatments [31,32]. It is uncertain how much the preventative effects alter based on the frequency and the form of preventive intervention and the corresponding measures. However, enhancing the frequency and the type of activity could help halt the spread of COVID-19.

Intense physical activity in densely populated rooms, for example in sports facilities in South Korea, could increase the risk for infection [33]. In a mosque, however, worship- 
pers are arranged in rows that are equidistant from one another. During the prayer, all worshippers in a row face the same direction. The space necessary for an average person to accomplish the act of prostration determines the spacing between the following rows. This spacing, which is roughly $120-150 \mathrm{~cm}$ on average, is routinely observed in mosques around the world. During the pandemic, the MUI issued a fatwa to pray at home or practice social distancing in congregational prayer in mosques as an effort to prevent the spread of COVID-19. This study shows that the prevalence of prayer distancing was high. The natural inter-row distance and the uniform direction of facing, coupled with protective measures in the form of prayer distancing, are likely to lessen the chance of COVID-19 transmission in mosques.

The duration of time people spend in a confined environment is connected to the probability of transmission. According to studies, 32 confirmed cases of transmission occurred among 61 participants during a 2.5-h Washington choir practice [34]. Similarly, research conducted in South Korea in a call center located on the ninth floor revealed that the majority of infections occurred with personnel sitting on the same side of the floor [35]. The Center for Disease Control and Prevention in the USA has thus set a minimal operational duration for the definition of contact at $15 \mathrm{~min}$ [36]. Meanwhile, the length of congregational prayer is determined by the number of units prayed. Though prayer units might range from two to four, the average length of congregational prayer remains around $10 \mathrm{~min}$ [37]. The peak density of worshippers is thus limited to $10 \mathrm{~min}$, with a sharp decrease occurring 5-10 min after communal prayer concludes. The duration of peak contact in a masjid is less than this, which is likely to be another protective feature. Not all crowds are created equal, and the behavioral dynamics of a specific crowd in a given setting are likely to be significant drivers of the rate of infection spread. This suggests that, despite bringing individuals together in a dense gathering, congregational prayer in mosques with reasonable protective measures may not facilitate the spread of the virus. In this regard, we can understand how religion could not contribute to the virus's propagation.

Nonetheless, all the findings above represent an alarming condition that is due to the low prevalence of congregational prayers at the mosque in Indonesia during the pandemic. In all eventualities, COVID-19 will remain with us for a long time, and its repercussions will be multi-layered according to these conceivable possibilities. As the world learns to live with COVID-19, countries confront their own difficulties and decisions, notably in how vaccinations, antivirals and non-pharmaceutical interventions are used [38]. We may have to live with COVID-19 for years to come. Therefore, adopting protective measures as nonpharmaceutical interventions remains to be improved in public spaces such as mosques.

\section{Conclusions}

In conclusion, the protective measures adopted by mosques are inadequate. The prevalence of the adoption of protective measures in mosques recommended by the MUI was approximately $44-92 \%$, and only $33.7 \%$ of the mosques in Surakarta City implemented all protective measures during the COVID-19 pandemic. The prevalence of protective measures in mosques affiliated with Nahdlatul Ulama and the small mosques were lower than in mosques affiliated with Muhammadiyah and the large mosques, suggesting that developing targeted health messages for these groups is crucial. Since the pandemic is still underway, implementing protective measures could be central to sustaining congregational prayers in mosques during pandemics. In addition, a campaign to promote compliance with the adoption of protective measures in mosques is required.

As religious communities worldwide have remained active throughout the outbreak of COVID-19, this study might also have significance for other countries with similar religious characteristics in their populations. There is a comparable worry over religious gatherings owing to the implicit danger of viral transmission. For believers to adopt public health policies, and for authorities to embrace and comprehend the importance of religious observances, the contradiction between medical and religious practices must be addressed in society. 
There are certain limitations to our research that should be considered. This investigation was undertaken during a period of high COVID-19 transmission rate, which is one of the most crucial points. As a result of variations in the status of the COVID-19 pandemic in Surakarta city and changes in mosque caretakers' arrangements in organizing congregational prayer activities, the prevalence of the adoption of protective measures could alter over time. Despite these shortcomings, this is, to the best of our knowledge, the first study to assess the status of the adoption of protective measures in mosques during the COVID-19 pandemic in Indonesia. The incidence of protective measures in mosques may differ in other Muslim communities with various cultural, ethnic and geographical backgrounds from those revealed in the current survey.

Author Contributions: Conceptualization, C.A. and P.P.; methodology, P.P.; software, C.A. and S.F.S.; validation, C.A., P.P. and U.U.; formal analysis, U.U.; investigation, C.A.; resources, P.P. and M.F.; data curation, C.A.; writing-original draft preparation, C.A.; writing—review and editing, P.P.; visualization, M.F.; supervision, U.U.; project administration, C.A.; funding acquisition, P.P. All authors have read and agreed to the published version of the manuscript.

Funding: This research was funded by Hibah Integrasi Perguruan Tinggi (HIT) Universitas Muhammadiyah Surakarta, grant number 1071/FGUMS/2021.

Institutional Review Board Statement: The study was conducted according to the guidelines of the Declaration of Helsinki, and approved by the Human Geography Research Ethics Committee of the Faculty of Geography of Universitas Muhammadiyah Surakarta on May 2021 (Reference No. 216/B.1/KEPGM-FGUMS/V/2021).

Informed Consent Statement: Informed consent was obtained from all subjects involved in the study.

Data Availability Statement: The data presented in the study are available on request from the corresponding author.

Acknowledgments: The authors would like to convey their gratitude to the experts who assisted with this study. We would like to thank all of the reviewers who provided feedback to help us improve this paper.

Conflicts of Interest: The authors declare no conflict of interest. The funders had no role in the design of the study, in the collection, analyses, or interpretation of data, in the writing of the manuscript, or in the decision to publish the results.

\section{References}

1. Shah, S.G.S. Doctors in Pakistan denounce opening of mosques for congregational prayers during Ramadan amid the COVID-19 pandemic: Correspondence. Int. J. Surg. 2020, 79, 40-41. [CrossRef] [PubMed]

2. Boston, W. More Than 100 in Germany Found to Be Infected with Coronavirus after Church's Services. Wall Street Journal. 24 May 2020. Available online: https://www.wsj.com/articles/more-than-100-in-germany-found-to-be-infected-with-coronavirusafter-a-churchs-services-11590340102 (accessed on 7 August 2021).

3. Cline, S. Church Tied to Oregon's Largest Coronavirus Outbreak. AP News, 17 June 2020. Available online: https://apnews. com/article/health-us-news-virus-outbreak-wa-state-wire-id-state-wire-b2d7a8af05e862dc3e1d1c3d0cf0afd0 (accessed on 7 August 2021).

4. Jeong, E.; Hagose, M.; Jung, H.; Ki, M. Understanding South Korea's Response to the COVID-19 Outbreak: A Real-Time Analysis. Environ. Res. Public Health 2020, 17, 9571. [CrossRef]

5. Kim, S.; Jeong, Y.D.; Byun, J.H.; Cho, G.; Park, A.; Jung, J.H.; Roh, Y.; Choi, S.; Muhammad, I.M.; Jung, I.H. Evaluation of COVID-19 epidemic outbreak caused by temporal contact-increase in South Korea. Int. J. Infect. Dis. 2020, 96, 454-457. [CrossRef] [PubMed]

6. Quadri, S.A. COVID-19 and religious congregations: Implications for spread of novel pathogens. Int. J. Infect. Dis. 2020, 96, 219-221. [CrossRef]

7. Chong, Y.M.; Sam, I.-C.; Chong, J.; Bador, M.K.; Ponnampalavanar, S.; Omar, S.F.S.; Kamarulzaman, A.; Munusamy, V.; Wong, C.K.; Jamaluddin, F.H.; et al. Sars-cov-2 lineage b.6 was the major contributor to early pandemic transmission in malaysia. PLoS Negl. Trop. Dis. 2020, 14, e0008744. [CrossRef]

8. Mat, N.F.C.; Edinur, H.A.; Razab, M.K.A.A.; Safuan, S. A single mass gathering resulted in massive transmission of COVID-19 infections in Malaysia with further international spread. J. Travel Med. 2020, 27, 1-4.

9. Baker, J.O.; Martí, G.; Braunstein, R.; Whitehead, A.L.; Yukich, G. Religion in the age of social distancing: How COVID-19 presents new directions for research. Sociol. Relig. 2020, 81, 357-370. [CrossRef] 
10. Yezli, S.; Khan, A. COVID-19 pandemic: It is time to temporarily close places of worship and to suspend religious gatherings. J. Travel Med. 2021, 28, taaa065. [CrossRef] [PubMed]

11. Wilder-Smith, A.; Freedman, D.O. Isolation, quarantine, social distancing and community containment: Pivotal role for old-style public health measures in the novel coronavirus (2019-nCoV) outbreak. J. Travel Med. 2020, 27, taaa020. [CrossRef]

12. Kowalczyk, O.; Roszkowski, K.; Montane, X.; Pawliszak, W.; Tylkowski, B.; Bajek, A. Religion and Faith Perception in a Pandemic of COVID-19. J. Relig. Health 2020, 59, 2671-2677. [CrossRef]

13. Sirry, M.; Omar, A.R. Muslim prayer and public spheres: An interpretation of the Qur'ānic verse 29:45. Interpret 2014, 68, 39-53. [CrossRef]

14. World Population Review. Indonesia Population. 2021. Available online: https://worldpopulationreview.com/countries/ indonesia-population (accessed on 9 June 2021).

15. Sulkowski, L.; Ignatowski, G. Impact of COVID-19 pandemic on organization of religious behaviour in different christian denominations in Poland. Religions 2020, 11, 254. [CrossRef]

16. WHO. Actions to Protect Ourselves. 2020. Available online: https://www.who.int/southeastasia/outbreaks-and-emergencies / covid-19/What-can-we-do-to-keep-safe/protective-measures/protect-ourselves (accessed on 15 March 2021).

17. MUI. Fatwa No. 14 of 2020-Organization of Worship in Situations of COVID-19 Outbreak. 2020. Available online: https: //mui.or.id/berita/27674/fatwa-penyelenggaraan-ibadah-dalam-situasi-terjadi-wabah-covid-19/ (accessed on 5 August 2021).

18. Qualls, N.; Levitt, A.; Kanade, N.; Wright-Jegede, N.; Dopson, S.; Biggerstaff, M.; Reed, C.; Uzicanin, A.; Frank, M.; Holloway, R.; et al. Community Mitigation Guidelines to Prevent Pandemic Influenza. MMWR Recomm. Rep. 2017, 66, 1-34. [CrossRef]

19. Piwko, A.M. Islam and the COVID-19 Pandemic: Between Religious Practice and Health Protection. J. Relig. Health 2021, 60, 3291-3308. [CrossRef]

20. Machida, M.; Nakamura, I.; Saito, R.; Nakaya, T.; Hanibuchi, T.; Takamiya, T.; Odagiri, Y.; Fukushima, N.; Kikuchi, H.; Kojima, T.; et al. Adoption of personal protective measures by ordinary citizens during the COVID-19 outbreak in Japan. Int. J. Infect. Dis. 2020, 94, 139-144. [CrossRef]

21. WHO. Indonesia Coronavirus (COVID-19) Situation. 2021. Available online: https://covid19.who.int/region/searo/country/id (accessed on 19 July 2021).

22. National COVID-19 Task Force. Data COVID-19 Indonesia Update 30 Mei 2021. 2021. Available online: https:/ / covid19.go.id/p/ berita/analisis-data-covid-19-indonesia-update-30-mei-2021 (accessed on 10 June 2021).

23. Hari, K. Pak Jokowi, the Coronavirus Has Hit Home, The Jakarta Post. 2020. Available online: https: / / www.thejakartapost.com/ academia/2020/03/21/pak-jokowi-the-coronavirus-has-hit-home.html (accessed on 10 July 2021).

24. Central Bureau of Statistics of Surakarta. Population by Religion in Surakarta. 2020. Available online: https://surakartakota.bps go.id/indicator/12/319/1/jumlah-penduduk-menurut-kelompok-umur-dan-jenis-kelamin.html (accessed on 19 April 2021).

25. Raosoft. Sample Size Calculator. 2021. Available online: http:/ / www.raosoft.com/samplesize.html (accessed on 30 April 2021).

26. Gravetter, F.J.; Wallnau, L.B. Statistics for the Behavioral Sciences. In Statistic for the Behavioral Science, 10th ed.; Cengage Learning: Boston, MA, USA, 2017.

27. Istratii, R. Restricting Religious Practice in the Era of COVID-19: A De-Westernised Perspective on Religious Freedom with Reference to the Case of Greece, Polit Theol. 2020. Available online: https://eprints.soas.ac.uk/32584/1/ RestrictingreligiouspracticeintheeraofCOVID-19.pdf (accessed on 1 December 2021).

28. Akhmad, B.A. Disparities in Health Communication of the Groups of Mosques in Responding to the Covid-19 Pandemic in Banjarmasin, South Kalimantan. J. Komun Ikat. Sarj. Komun. Indones. 2020, 5, 10-17. [CrossRef]

29. Atchison, C.; Bowman, L.; Eaton, J.W.; Imai, N.; Redd, R.; Pristera, P.; Vrinten, C.; Ward, H. Public Response to UK Government Recommendations on COVID-19: Population Survey, 17-18 March 2020. 2020. Available online: https:/ / www.imperial.ac.uk/ mrc-global-infectious-disease-analysis/covid-19/report-10-population-survey-covid-19/ (accessed on 28 September 2021).

30. FDA. Non-Contact Temperature Assessment Devices During the COVID-19 Pandemic. 2021. Available online: https: / / www.fda.gov/medical-devices / coronavirus-covid-19-and-medical-devices/non-contact-temperature-assessment-devicesduring-covid-19-pandemic (accessed on 16 August 2021).

31. European Centre for Disease Prevention and Control (ECDC). Guidelines for the Use of Non-Pharmaceutical Measures to Delay and Mitigate the Impact of 2019- nCoV. 2020. Available online: https: / /www.ecdc.europa.eu/en/publications-data/covid-19 -guidelines-non-pharmaceutical-interventions (accessed on 15 June 2021).

32. Liu, S.F.; Chang, J.F.; Wang, M.H. Mask design for life in the midst of covid-19. Sustainability 2021, 13, 8011. [CrossRef]

33. Jang, S.; Han, S.H.; Rhee, J.-Y. Cluster of Coronavirus Disease Associated with Fitness Dance Classes, South Korea. Emerg. Infect. Dis. 2020, 26, 1917-1920. [CrossRef]

34. Naunheim, M.R.; Bock, J.; Doucette, P.A.; Hoch, M.; Howell, I.; Johns, M.M.; Johnson, A.M.; Krishna, P.; Meyer, D.; Milstein, C.F.; et al. Safer Singing During the SARS-CoV-2 Pandemic: What We Know and What We Don't. J. Voice 2021, 35, 765-771. [CrossRef]

35. Park, S.Y.; Kim, Y.-M.; Yi, S.; Lee, S.; Na, B.; Kim, C.B.; Kim, J.-I.; Kim, H.S.; Park, Y.; Huh, I.S.; et al. Coronavirus Disease Outbreak in Call Center, South Korea. Emerg. Infect. Dis. 2020, 26, 1666-1670. [CrossRef]

36. CDC. Public Health Guidance for Community-Related Exposure. Centers for Desease Control and Prevention, 2020. Available online: https:/ / www.cdc.gov / coronavirus/2019-ncov/php/public-health-recommendations.html\#print (accessed on 9 July 2021). 
37. Hashmi, T.; Aldahe, A.; Zidan, M. Muslim congregational prayer and COVID19 transmission. Int. J. Med. Rev. Case Rep. 2020, 4, 57-59. [CrossRef]

38. Bedford, J.; Berglof, E.; Buckee, C.; Farrar, J.; Grenfell, B.; Holmes, E.C.; Metcalf, C.J.E.; Sridhar, D.; Thompson, B. COVID-19 Futures: A Framework for Exploring Medium and Long-Term Impacts. Soc. Sci. Res. Netw. 2020, 1, 215-228. [CrossRef] 